\title{
Colored Plastic Mulch Effects on Plant Performance and Disease Suppression in Organically Grown Bell Pepper (Capsicum annuum)
}

\author{
Leopold M. Nyochembeng ${ }^{1} \&$ Regine N. Mankolo ${ }^{1}$ \\ ${ }^{1}$ Department of Biological and Environmental Sciences, Alabama A\&M University, Normal, AL, USA \\ Correspondence: Leopold M. Nyochembeng, Department of Biological and Environmental Sciences, Alabama \\ A\&M University, Normal, AL 35762, USA. Tel: 1-256-372-4218. E-mail: leopold.nyochembeng@aamu.edu
}

Received: February 20, 2021

Accepted: April 9, $2021 \quad$ Online Published: May 15, 2021

doi:10.5539/jas.v13n6p11

URL: https://doi.org/10.5539/jas.v13n6p11

The research is financed by USDA-National Institute of Food and Agriculture Evans-Allen project ALAX-011-0914.

\begin{abstract}
Weeds and diseases are major biological competitors that pose significant threats to organic production of vegetables in southeastern US during the summer. We evaluated plasticulture as an alternative weed and disease management strategy for open field organic production of bell peppers. The objective of the research was to assess the effects of four colored plastic mulches on soil temperature, moisture, fruit yield and suppression of weeds and diseases on bell pepper. Bell pepper cv 'King Arthur' was planted on raised soil beds covered with colored (olive green, black, white and silver) mulch treatments including a control (bare soil). The experimental design was a randomized complete block with four replications. Soil temperature and moisture, disease incidence and severity, and fruit yield were determined. Plant performance (growth and yield) varied with mulch type. The black and olive plastic mulches warmed the soil significantly more than the reflective silver and bare soil. Bell pepper plants across all mulch treatments exhibited susceptibility to bacterial leaf spot (BLS). However, the incidence and severity of BLS varied with mulch type. Plants on reflective silver plastic displayed significant BLS incidence and severity compared to the olive plastic and bare soil. The black, white, and reflective silver plastic mulches significantly increased fruit yields, while the olive mulch and bare soil exhibited poor crop performance. These results suggest that the black and white plastic mulches retain the potential to be used in organic vegetable production in Alabama and the southeastern US.
\end{abstract}

Keywords: bacterial leaf spot, bell pepper, organic, plastic mulch, plasticulture

\section{Introduction}

Plasticulture on raised beds has been practiced for decades due to several agronomic benefits including early season crop production, increased yield per unit area, better fruit quality, improved water use efficiency, elimination of weed competition, and management of insect pests and diseases (Anderson et al., 2012). Weeds and diseases are major constraints to organic vegetable production during the summer in southeastern US. Weeds compete with crops for sunlight, nutrients and moisture, and may be alternate hosts of important crop diseases. In organic vegetable production system, several sustainable and ecofriendly tactics are employed for the management of pests and diseases, including the use of plastic mulches. Polyethylene mulch modifies the microclimate of the soil beneath it and of the atmosphere above it (Tarara, 2000). Black plastic increased root length, root length density, and root diameter in corn (Sun et al., 2018). Owing to their humidity lowering effect, these soil bed covers have been suggested as a means to minimize the development of some foliar diseases such as gray mold (Elad, 2000). Mulching with polyethylene is hypothesized to create conditions within the plant canopy which are less favorable to disease development (Shtienberg et al., 2010). Plastic mulches have also been used to effectively reduce white mold disease caused by Sclerotinia sclerotiorum in basil (Elad et al., 2015). UV-reflective metal coated plastic mulches are increasingly being tested to ward off insect pests and insect vectors of many viral diseases including tomato spotted wilt virus. Murphy et al. (2009) observed that reflective plastic mulch reduced watermelon mosaic virus incidence and yield losses in squash. Recently, plastic mulching was demonstrated to contribute to the management of the soilborne plant pathogenic bacterium Ralstonia solanacearum cause of bacterial wilt of solanaceous crops such as tomato (Chen et al., 2020). In Alabama and 
the southeastern US, plasticulture is gaining attention in organic production systems to manage weeds and plant diseases and produce healthy organic fruits and vegetables. The objective of this research was to assess the effects of colored plastic mulches on soil temperature, moisture, fruit yield, and suppression of weeds and diseases in open field organic production of bell pepper in Alabama.

\section{Materials and Methods}

\subsection{Experimental Site}

The experiments were conducted on Decatur silty clay loam (Clayey, Kaolinitic, Thermic Rhodic Paleudults) at Winfred Thomas Agricultural Research Station (WTARS) of Alabama A\&M University in Hazel Green, Alabama $\left(34^{\circ} 56^{\prime} \mathrm{N}, 86^{\circ} 34^{\prime} \mathrm{W}\right)$ on land used exclusively for organic vegetable research. The meteorological data (rainfall and temperature) during the growing seasons are as shown in Figure 1.

\subsection{Land Preparation and Planting}

The experimental plot was doubled-disked and raised beds $5 \mathrm{~m} \times 0.9 \mathrm{~m}$ prepared, drip irrigation tape was installed at the center of the beds which were covered with colored (olive green, black, white and reflective silver) mulch treatments including a control (no mulch or bare soil). Bell pepper cv 'King Arthur' seedlings were planted in the middle of the raised beds at intra-row spacing of $45 \mathrm{~cm}$ in May. Holes about $10 \mathrm{~cm}$ wide and $8 \mathrm{~cm}$ deep were punched through the plastic or directly into the soil bed (control) for placing the pepper seedling transplants. About $70 \mathrm{~kg} / \mathrm{ha} \mathrm{N}$ was applied as pelletized poultry liter (4-3-2 NPK) after seedling establishment and thereafter, Multibloom (Hydrolysate Company of America, Isola, MS) was applied through fertigation to the plants providing a total of $135 \mathrm{~kg} \mathrm{~N} / \mathrm{ha}$. The control (bare soil) plots were manually weeded twice during the growing season to minimize weed pressure. The planted beds were irrigated through drip tape for two hours each day throughout the growing season.

\subsection{Experimental Design and Data Collection}

The experiment was laid out as a randomized complete block design with four replications. Soil temperature was measured with a pivoting digital thermometer at a soil depth of $12 \mathrm{~cm}$. Soil moisture was determined by soil analysis. Seedling establishment and plant survival, diseases (anthracnose of bell pepper, bacterial leaf spot, southern blight) incidence (\% of diseased plants out of total observed) and disease severity (assessed using a score of $0-5$ where $0=$ no disease and $5=81 \%-100 \%$ symptomatic foliage/fruit or dead plant) were measured during crop growth. Fruit yield was determined at harvest in August as number of fruits/plant and fruit weight in $\mathrm{kg} / \mathrm{plant}$. All data were subjected to analysis of variance (ANOVA) procedure in Statistical Analysis System (SAS 9.1) software and significant treatment (colored mulches) means were separated using Tukey's HSD test at $\mathrm{P}=5 \%$. The experiments were repeated over two growing seasons.

\section{Results and Discussion}

This research was conducted as part of our continued effort to improve cultural practices for efficient sustainable production of organic vegetables in limited resource farms in north Alabama and the southeastern region. The goal was to understand the role of colored mulches in crop responses to diseases and other environmental growth factors such as soil temperature and moisture. 


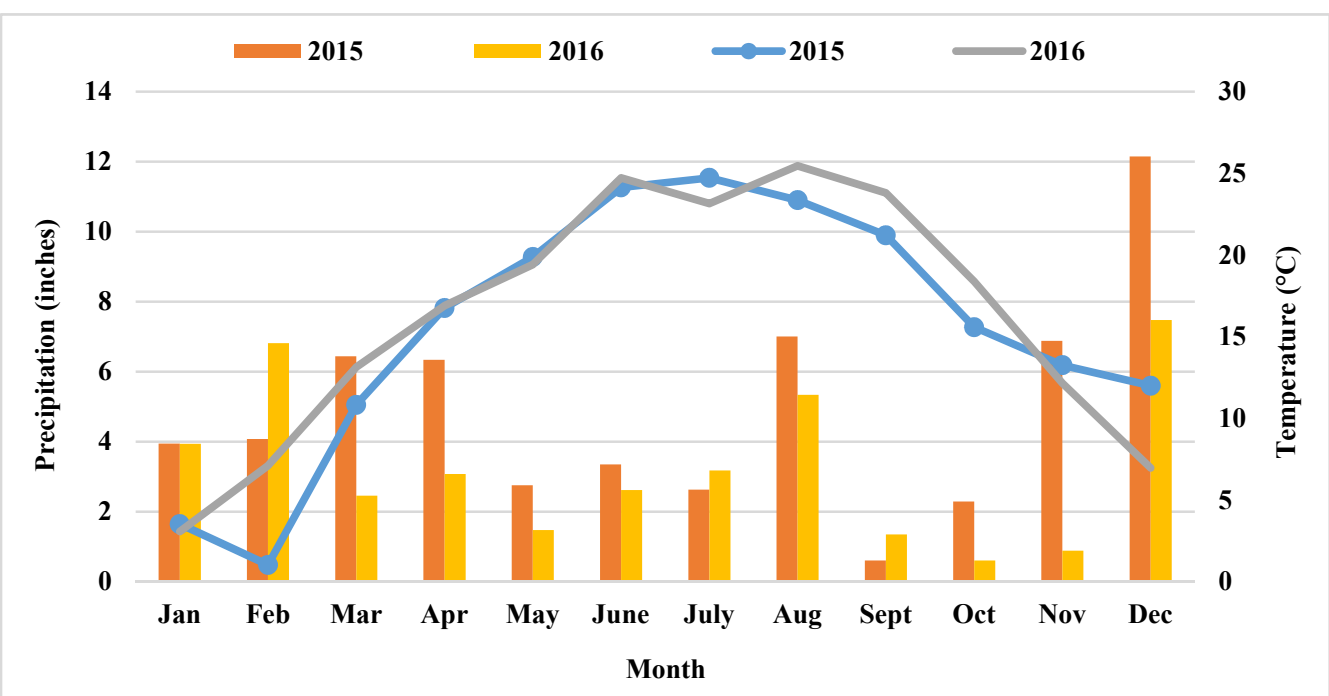

Figure 1. Monthly rainfall (precipitation) and temperatures recorded at the Eddy Covariance Flux Station at the Winfred Thomas Agricultural Research Station (experimental site) during the 2015 and 2016 growing seasons

The amount of rainfall in 2015 was more than in 2016, however, the pattern (wavy) was similar in both years (Figure 1). Owing to the similarity in crop performance data in the two growing seasons, the data presented (soil temperature, crop yield, disease incidence and severity) is averaged for the two seasons. The mean monthly temperatures followed the same trend for both years. The mean daily temperatures during the two cash-crop growing seasons ranged from $19.4{ }^{\circ} \mathrm{C}$ to $25.4{ }^{\circ} \mathrm{C}$.

Black and olive plastic mulches warmed the soil more than reflective silver and the control (bare soil) and the temperature of the soil beneath the plastic mulches was significantly higher and influenced by the color of the plastic mulch (Figure 2). The mean soil temperatures at $12 \mathrm{~cm}$ depth beneath the reflective silver, white, black and olive colored plastic mulches were respectively $-0.5^{\circ} \mathrm{C}, 0.5^{\circ} \mathrm{C}, 4{ }^{\circ} \mathrm{C}$ and $4.4{ }^{\circ} \mathrm{C}$ above the mean temperature of the bare soil (control). As expected, the black and olive colored plastic mulches retained more heat due to their darker colors. In a lettuce (Lactuca sativa L.) production system, the darker colored plastic mulches used were also observed to absorb solar energy more readily (Franquera \& Mabesa, 2016).

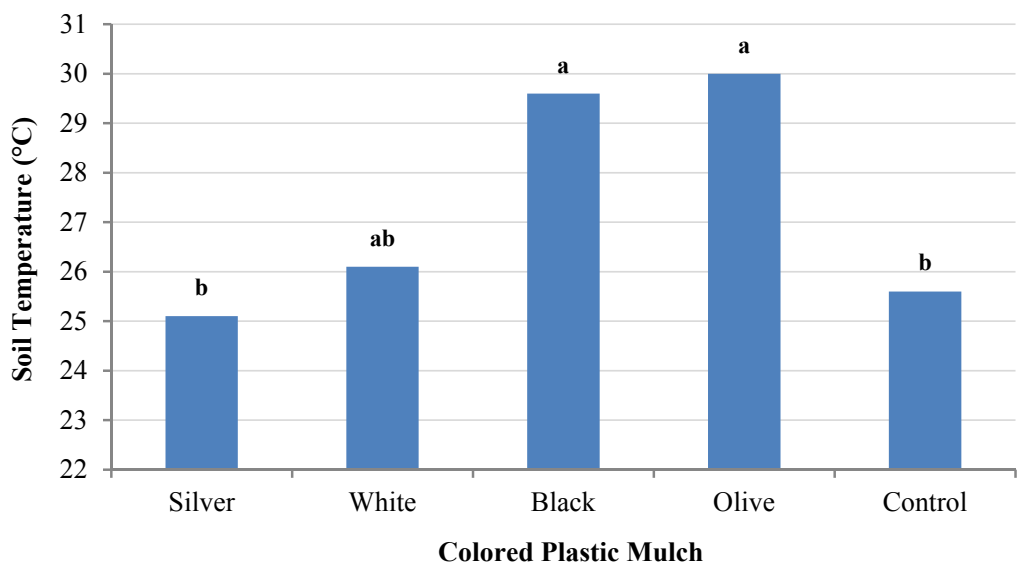

Figure 2. Soil temperature measured beneath the plastic mulches at a soil depth of $12 \mathrm{~cm}$ over two growing seasons

Soil moisture ranged from $12 \%$ to $22 \%$ within the $0-10 \mathrm{~cm}$ depth and from $16 \%$ to $22 \%$ in the $10-20 \mathrm{~cm}$ depth (Figure 3.). Soil moisture under black and reflective silver plastic was lower at the $0-10 \mathrm{~cm}$ depth and higher at the 10-20 cm depth; did not vary with depth under white and olive green plastic mulches. Bare soil had the highest moisture at the $0-10 \mathrm{~cm}$ depth due to rainfall and vegetation cover that included some weeds. 


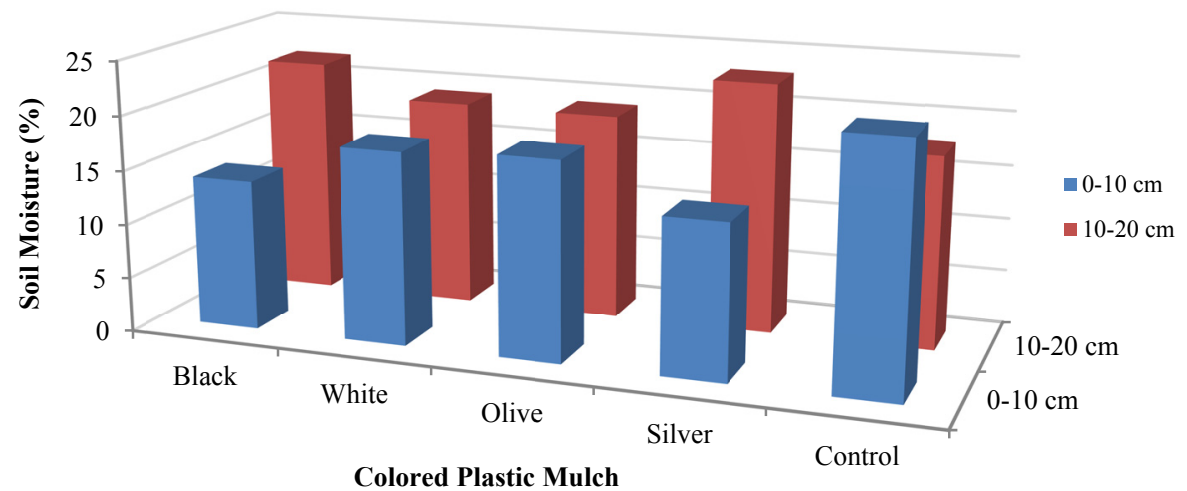

Figure 3. Soil moisture under plastic mulches and bare soil measured at soil depth of 0-10 cm and $10-20 \mathrm{~cm}$

Plant performance (growth and yield) varied with mulch type. Reflective silver, black, and white plastic mulches significantly increased the number of bell pepper fruits/plant (Figure 4A) and fruit weight (Figure 4B). All colored mulches (black, reflective silver, white) except the olive green plastic mulch increased bell pepper fruit weight by up to $1.06 \mathrm{~kg} /$ plant in comparison with bare soil. Farias-Larios and Orozco-Santos (1997) observed a similar trend in which clear, black and white plastic mulches increased fruit weight and yield in watermelon compared to production on bare soil. Most marketable (larger, heavier and blemish-free) fruits were obtained from plants grown on white plastic mulch.

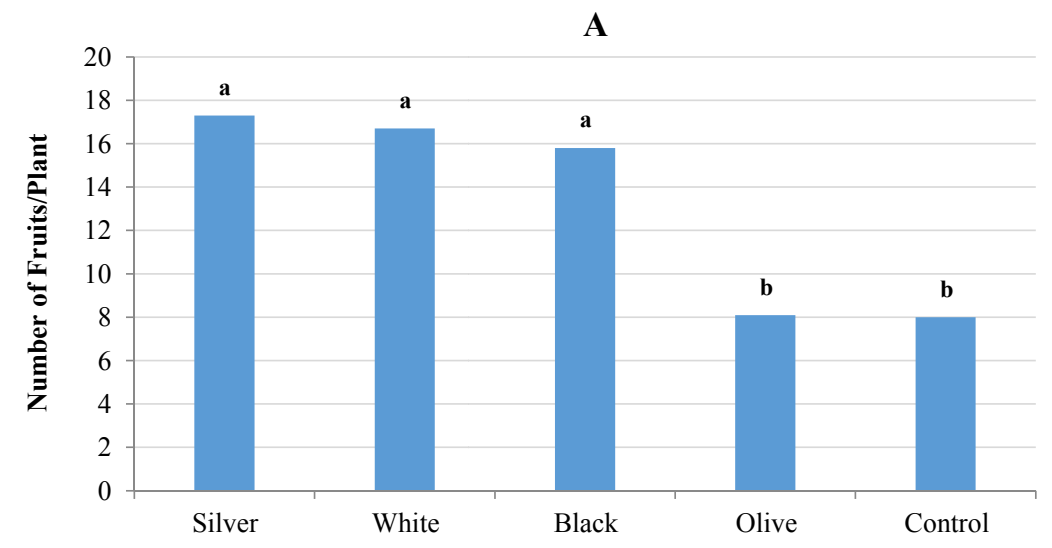

B

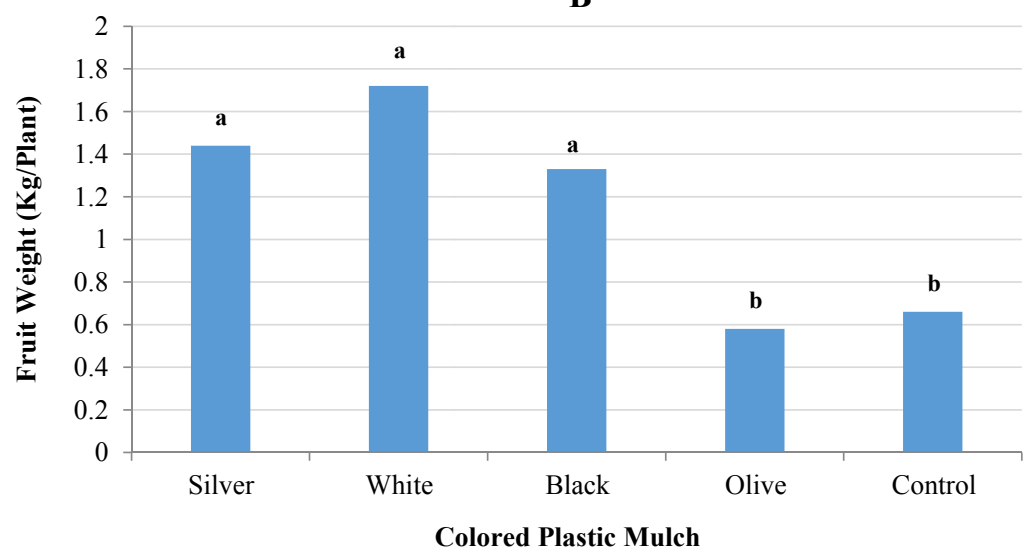

Figure 4. Yield of bell pepper determined by the number fruits/plant (A) and fruit weight (kg/plant) (B) as influenced by various colored mulches and bare soil (control) treatments 
Plastic mulch had no effect on incidence and severity of anthracnose of bell pepper (data not shown) which although present in the field did not spread significantly. However, the incidence and severity of bacterial spot (BLS) disease were significantly higher in the reflective silver mulch treatment and less in olive plastic and bare soil treatments (Figures 5A and 5B).

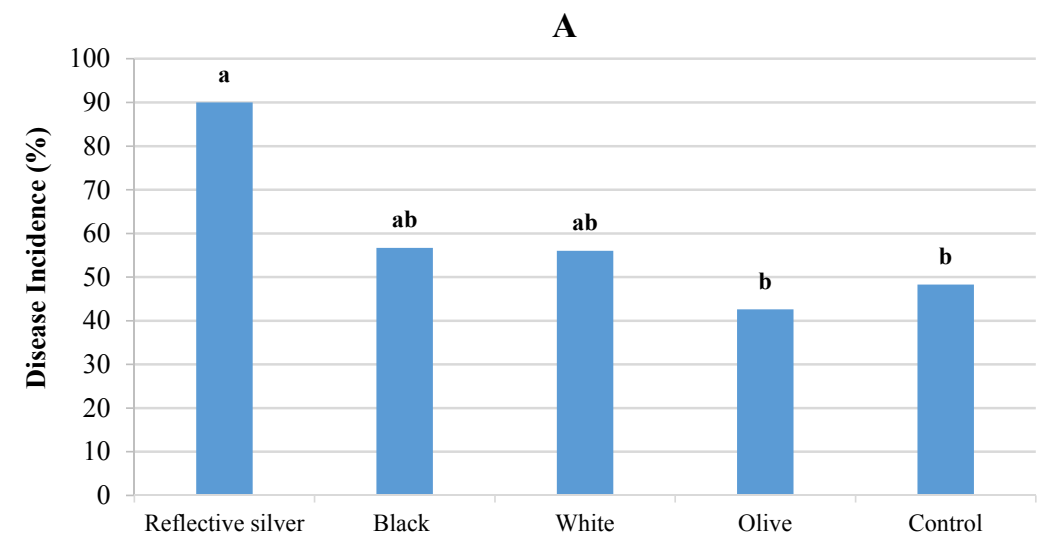

B

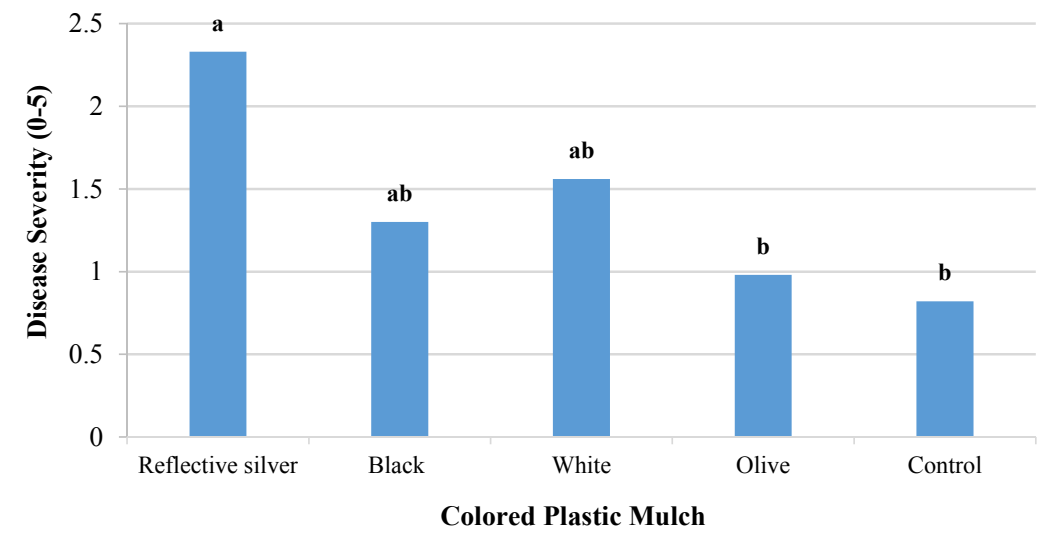

Figure 5. Bacterial spot incidence (A) and severity (B) in bell pepper 'King Arthur' under different mulch treatments

The relatively high bacterial spot disease incidence and severity observed in the reflective silver mulch treatment is not well understood. However, it could be attributable to light reflection effects. Reflective mulches and white mulches can influence the amount and quality of light wavelengths reflected into the plant canopy (Ham et al., 1993; Hutton \& Handley, 2007). Diaz-Perez (2010) measured the photosynthetically active radiation (PAR) reflected by silver plastic mulch into bell pepper canopy in the fall season to be $52 \%$ which was the highest among other mulch types including white and black. These reflected wavelengths could have an impact on bacterial spot incidence and severity. The significance of light in microbial pathological processes and disease development in plants has become increasingly evident. Light affects plant defense responses and the virulence of and infection by plant pathogenic bacteria (Nagendran \& Lee, 2015; Gomelsky \& Hoff, 2011; Oberpichler et al., 2008). The silver reflective mulch increases the amount of light entering the plant canopy, which might play a role in bacterial spot infection. In a previous study, we had observed that reflective silver plastic mulch significantly exhibited high bacterial leaf spot severity in tomato compared to no mulch treatment (Nyochembeng et al., 2014). Although polyethylene mulches including the reflective silver much are used beneficially to modify the plant microclimate, such modification may not be detrimental to the development of some foliar pathogens of bell pepper including bacterial leaf spot. Reflective silver plastic mulch has been used to control insect vectors of plant diseases such as thrips that vector tomato spotted wilt virus. In this study, we observed that reflective silver plastic mulch enhanced the incidence of bacterial leaf spot disease in pepper. 
The reduction of disease in the control treatment could be attributed to the weeds in the control which acted as a 'buffer' to the disease spread as previously observed (Nyochembeng et al., 2014), by shielding the pepper plants and also consequently causing a reduction in fruit yield. Both incidence and severity of bacterial spot disease varied based on mulch type. The black and white plastic mulches significantly increased fruit yields while the olive mulch exhibited poor crop performance.

\section{Conclusions}

Weeds and diseases are major constraints to organic vegetable production in Alabama and southeastern US during the summer months. Bell pepper production is more successful under plasticulture mainly due to weed elimination and soil moisture retention. Producers commonly use black plastic mulch, and occasionally, reflective silver plastic for control of some insect pests such as thrips. In this study, reflective silver plastic mulch appeared to be favorable to bacterial spot disease in bell pepper cv 'King Arthur'. Although the olive plastic mulch showed low disease incidence, it exhibited the poorest crop performance in growth and yield. The black and white plastic mulches retained the potential for use in organic production of bell pepper in North Alabama.

\section{Acknowledgements}

The research was support by USDA-NIFA Evans-Allen grant ALAX-011-0914.

\section{References}

Anderson, P. C., Olsen, S. M., \& Momol, M. T. (2012). Effect of plastic mulch type and insecticide on incidence of tomato spotted wilt, plant growth, and yield of tomato. HortScience, 47, 861-865. https://doi.org/ 10.21273/HORTSCI.47.7.861

Chen, K., Khan, R. A. A., Cao, W., \& Ling, M. (2020). Sustainable and ecofriendly approach of managing soilborne bacterium Ralstonia solanacearum (Smith) using dried powder of Conyza canadensis. Pathogens, 9(5), 327. https://doi.org/10.3390/pathogens 9050327

Diaz-Perez, J. C. (2010). Bell pepper (Capsicum annuum L.) grown on plastic film mulches: Effects on crop microenvironment, physiological attributes, and fruit yield. HortScience, 45(8), 1196-1204. https://doi.org/ 10.21273/HORTSCI.45.8.1196

Elad, Y. (2000). Changes in disease epidemics on greenhouse grown crops. Acta Hort., 534, 213-220. https://doi.org/10.17660/ActaHortic.2000.534.24

Elmer, W. H. (2000). Comparison of plastic mulch and nitrogen forms on incidence of verticillium wilt of eggplant. Plant Disease, 84, 1231-1234. https://doi.org/10.1094/PDIS.2000.84.11.1231

Farias-Larios, J., \& Orozco-Santos, M. (1997). Effect of polyethylene mulch color on aphid populations, soil temperature, fruit quality, and yield of watermelon under tropical conditions. New Zealand Journal of Crop and Horticultural Science, 25, 369-374. https://doi.org/10.1080/01140671.1997.9514028

Franquera, E. N., \& Mabec, R. C. (2016). Colored plastic mulch effects on the yield of lettuce (Lactuca sativa L.) and soil temperature. J. Advanced Agricultural Technologies, 3(3), 155-159. https://doi.org/10.18178/joaat. 3.3.155-159

Gomelsky, M., \& Hoff, W. D. (2011). Light helps bacteria make important lifestyle decisions. Trends Microbiol., 19, 441-448. https://doi.org/10.1016/j.tim.2011.05.002

Ham, J.M., Kluitenberg, G.J. \& Lamont, W.J. (1993). Optical properties of plastic mulches affect the field temperature regime. J. Amer Soc. Hort Sci., 228(2), 188-193. https://doi.org/10.21273/JASHS.118.2.188

Hutton, M. G., \& Handley, D. T. (2007). Effect of silver reflective mulch, white inter-row mulch and plant density on yields of pepper in Maine. HortTechnology, 17, 214-219. https://doi.org/10.21273/HORTTECH. 17.2.214

Murphy, J. F., Eubanks, M. D., \& Masiri, J. (2009). Reflective plastic mulch but not a resistance-inducing treatment reduced watermelon mosaic virus incidence and yield losses in squash. International $J$. of Vegetable Sci., 15, 3-12. https://doi.org/10.1080/19315260802446351

Nagendran, R., \& Lee, Y. H. (2015). Green and red light reduces the disease severity by Pseudomonas cichorii $\mathrm{JBC} 1$ in tomato plants via upregulation of defense-related gene expression. Phytopathology, 105, 412-418. https://doi.org/10.1094/PHYTO-04-14-0108-R 
Nyochembeng, L. M., Mankolo, R. N., Mentreddy, S. R., \& Mayalagu, G. (2014). Cover crop, reflective polyethylene mulch and biofungicide effects on yield and management of diseases in field-grown organic tomato. J. Agricultural Science, 6, 265-275. https://doi.org/10.5539/jas.v6n12p265

Nyoike, T. W., \& Liburd, O. E. (2014). Reusing plastic mulch for a seasonal strawberry crop: effects of arthropod pests, weeds, diseases and strawberry yield. Florida Entomologist, 97, 928-936. https://doi.org/ $10.1653 / 024.097 .0351$

Oberpichler, I., Rosen, R., Rasouly, A., Vugman, M., Ron, E. Z., \& Lamparter, T. (2008). Light affects motility and infectivity of Agrobacterium tumefaciens. Environ. Microbiol., 10, 2020-2029. https://doi.org/10.1111/ j.1462-2920.2008.01618.x

Shtienberg, D., Elad, Y., Bornstein, M., Ziv, G., Grava, A., \& Cohen, S. (2010). Polyethylene mulch modifies greenhouse microclimate and reduces infection of Phytophthora infestans in tomato and Pseudoperenospora cubensis in cucumber. Phytopathology, 100, 97-104. https://doi.org/10.1094/PHYTO-100-1-0097

Sun, S., Chen, Z., Jiang, H., \& Zhang L. (2018). Black film mulching and plant density influencing soil water temperature conditions and maize root growth. Vadose Zone J, 17(1), 1-12. https://doi.org/10.2136/vzj2018. 05.0104

Tarara, M. J. (2000). Microclimate modification with plastic mulch. HortScience, 35, 169-180. https://doi.org/ 10.21273/HORTSCI.35.2.169

\section{Copyrights}

Copyright for this article is retained by the author(s), with first publication rights granted to the journal.

This is an open-access article distributed under the terms and conditions of the Creative Commons Attribution license (http://creativecommons.org/licenses/by/4.0/). 